\title{
ANALISIS PERUBAHAN PENGGUNAAN LAHAN DAN DAMPAKNYA TERHADAP HASIL AIR DI DAS CISADANE HULU
}

\author{
Nilda ${ }^{1}$, I Wayan Sandi Adnyana ${ }^{2}$, I Nyoman Merit ${ }^{2}$ \\ ${ }^{1}$ Program Studi Magister Ilmu Lingkungan, Universitas Udayana Bali \\ ${ }^{2}$ Fakultas Pertanian, Universitas Udayana Bali \\ *Email:inne1391@yahoo.com
}

\begin{abstract}
ABSTRAK
Air merupakan salah satu kebutuhan dasar yang sangat penting bagi manusia. Terdapat beberapa faktor utama penyebab perubahan sumber daya air, diantaranya adalah perubahan penutupandan pengelolaan lahan yang meningkatkan kekedapan lahan. Salah satu tujuan pengelolaan DAS adalah mencapai kondisi tata air optimal yang dapat dikenali dari sifat aliran sungai. Penelitian ini bertujuan untuk: (1) mengetahui distribusi perubahan penggunaan lahan yang terjadi di wilayah DAS Cisadane Hulu dari tahun 2003 sampai 2010; (2) mengetahui perubahan hasil air akibat distribusi perubahan penggunaan lahan. Daerah kajian penelitian adalah DAS Cisadane Hulu dengan luasan sekitar 22.288,01 ha.

Penelitian dilakukan melalui dua tahap yaitu analisis perubahan penggnaan lahan dan prediksi aliran dengan model HEC-HMS. Dalam penelitian ini digunakan peta pengunaan lahan dari BIG (Badan Informasi Geospasial) tahun 2003 dan Peta Penggunaan Lahan tahun 2010 hasil interpretasi Citra ALOS. Selanjutnya kedua peta tersebut dianalisis dengan metoda tabel silang (cross tabel) untuk memperoleh data perubahan penggunaan lahan dari setiap kelas penggunaannya. Kedua data series penggunaan lahan ini digunakan sebagai input pada model prediksi debit aliran HEC-HMS. Selanjutnya dibangun juga skenario-skenario untuk melihat dampak perubahan lahan terhadap debit aliran di DAS Cisadane Hulu. Metode bilangan kurva (SCS-CN) dipilih untuk menghitung besar curah hujan efektif, yaitu dari pengurangan curah hujan bruto dengan berbagai bentuk kehilangan air (loss). Transformasi dari curah hujan efektif menjadi hidrograf aliran langsung (direct runoff) diperoleh dengan menggunakan metode hidrograf satuan SCS Curve Number.

Selama kurun waktu 2003 - 2010 terjadi perubahan penggunaan lahan di DAS Cisadane Hulu. Luas Hutan bertambah 223,78 ha, pemukiman 214,78 ha, rumput/tanah kosong 85, 73 ha, dan gedung 12,64 ha. Terjadi penguarangan luas semak belukar 225,64 ha, tegalan/ladang 145,92 ha, sawah irigasi 124, 92 ha, sawah tadah hujan 30,67 ha, dan kebun/perkebunan 9,92 ha.

Hasil dari simulasi dengan menggunakan peta penggunaan lahan tahun 2010 didapatkan nilai debit puncak (Qp) sebesar $81.73 \mathrm{~m}^{3} /$ detik. Nilai volume puncak (Vp) sebesar 2,310.7 mm dan Waktu Puncak (Tp) pada hidrograf aliran yang dihasilkan model terjadi pada tanggal 26 Maret 2010. Secara umum terjadi peningkatan debit puncak antara penggunaan lahan tahun 2003 dengan 2010. dari $81.22 \mathrm{~m}^{3} /$ detik menjadi $81.73 \mathrm{~m}^{3} /$ detik. Naiknya debit puncak disebabkan meningkatnya aliran permukaan akibat perkembangan pemukiman di DAS.Hal ini terlihat dengan meningkatnya nilai CN rata-rata dari 38.5 menjadi 39.4.Pada simulasi dengan penggunaan lahan tahun 2010 didapatkan hasil airsebesar 2.310,7 mm/tahun. Nilai ini lebih kecil dari simulasi dengan penggunaan lahan tahun 2003 yaitu 2.320,1 mm/tahun. Salah satu penyebab berkurangnya hasil air dapat dikarenakan penguapan yang meningkat akibat bertambahnya luasan hutan. (banyaknya pemanfaat air tanah disekitar DAS tersebut, baik legal maupun ilegal).
\end{abstract}

Kata Kunci: Daerah Aliran Sungai;Perubahan Penggunaan Lahan; Hasil Air.

\section{PENDAHULUAN}

Perubahan pola penggunaan lahan untuk kegiatan lain tentu memberikan manfaat sosial dan ekonomi, namun,seringkali berdampak sebaliknya terhadap lingkungan karena menurunkan luas hutan, keanekaragaman hayati, meningkatkan luas lahan kritis, erosi dan longsor akibat adanya perubahan penggunaan lahan yang tidak sesuai. Konversi lahan pertanian, hutan, rumput, dan lahan basah untuk daerah perkotaan biasanya menyebabkan peningkatan aliran air di permukaan tanah, yang dapat mengubah kondisi hidrologi alami daerah aliran sungai (DAS). Hal ini karena menurunnya kemampuan infiltrasi tanah dan meningkatkan aliran permukaan.

DAS merupakan suatu sistem alami dalam hidrologi dengan sungai sebagai komponen utama. Aliran sungai sangat dipengaruhioleh karakteristik curah hujan dan kondisi biofisik DAS.Karakteristik biofisik mencakup geometri (ukuran, bentuk, kemiringan DAS), morfometri (ordo sungai, kerapatan jarigan sungai, rasio percabangan, rasio pajang), geologi, serta penutupan lahan (Liamas, 1993; Kartiwa et al., 2005). 
Perubahan penggunaan lahan yang tidak terkendali dan tanpa tindakan konservasi tanah dan air akan menyebabkan terjadinya erosi. Erosi yang terjadi dapat menyebabkan degradasi lahan, yang akhirnya menyebabkan menurunnya produktivitas lahan (Adnyana, 2011).

Guna mengetahui adanya perubahan penggunaan lahan pada suatu wilayah, dapat diperoleh melalui beberapa metode, antara lain melalui penggunaan data pengindaraan jauh dan Sistem Informasi Geografis (SIG). Hasil analisa SIG dapat digunakan untuk mendukung pengambilan keputusan dalam perencanaan dan pengelolaan wilayah. Integrasi antara SIG dengan pemodelan hidrologi dan pemodelan penggunaan lahan memudahkan aktifitas manajemen data, sehingga memudahkan dalam mengekstraksi beberapa parameter model secara efisien dalam skala DAS. Penggunaan model untuk mengetahui perubahan penggunaan lahan dikombinasikan dengan perkembangan model hidrologi memungkinkan prediksi yang lebih realistis dari sistem hidrologi di masa depan. Melalui penelitian ini perubahan penggunaan lahan dan proses hidrologi digunakan untuk mencari hasil air, membuat perhitungan cepat untuk mendapatkan aliran puncak (peak runoff) dengan ketersediaan data yang terbatas.

Rumusan Masalah yaitu mengetahui bagaimana perubahan penggunan lahan yang terjadi di DAS Cisadane Hulu sejak tahun 2003 sampai dengan tahun 2010 serta bagaimana dampak akibat adanya perubahan penutupan lahan tersebut terhadap debit air. Penelitian ini bertujuan untuk mengetahui distribusi perubahan penggunaan lahan yang terjadi di wilayah DAS Cisadane Hulu dalam kurun waktu sejak tahun 2003 sampai dengan tahun 2010, dan untuk mengetahui perubahan hasil air dari adanya distribusi perubahan penggunaan lahan di DAS Cisadane Hulu.

Hasil penelitian ini diharapkan dapat bermanfaat untuk mengetahui penyebab terjadinya peningkatan atau pengurangan ketersediaan air yang kemungkinan disebabkan oleh perubahan penggunaan lahan. Dari analisa terhadap hasil penelitian gabungan dari model prediksi perubahan penggunaan lahan dan model hidrologi, diharapkan dapat diketahui langkah yang harus dilakukan dalam pengelolaan DAS di Cisadane Hulu, juga dapat digunakan pada DAS- DAS lainnya.

\section{METODE}

\subsection{Lokasi Dan Waktu Penelitian}

Penelitian ini dilakukan pada DAS Cisadane Hulu yang merupakan salah satu dari dua hulu DAS Cisadane.yang berada di pegunungan GedePangrango, dengan daerah tangkapan mencapai luas
22.228,01 ha. Waktu penelitian dilaksanakan mulai bulan Oktober 2012 hingga Desember 2012.

\subsection{Penentuan Sumber Data}

Sumber data yang digunakan pada penelitian ini terdiri dari data primer dan data sekunder. Data primer diperoleh melaui observasi langsung, pengamatan lapangan untuk mengetahui kondisi fisik di DAS Cisadane Hulu. Data primer yang dibutuhkan diantaranya adalah kondisi penggunaan lahan, data debit air dan karakteristik tanah di DAS Cisadane Hulu.

Data sekunder diperoleh melalui pengumpulan data kondisi umum DAS Cisadane Hulu baik data penggunaan lahan maupun data karakteristik DAS. Data yang dibutuhkan untuk proses analisis penggunaan lahan diantaranya adalah data Citra ALOS-AVNIR dengan resolusi 10 meter, untuk kawasan DAS Cisadane Hulu, Tahun 2010; Peta Rupa Bumi Indonesia, skala 1:25.000; serta Digital Elevation Model (DEM), $90 \mathrm{~m}$. Sedangkan untuk analisis hidrologi dibutuhkan data peta tanah, debit harian, hujan harian dan karakteristik DAS.

\subsection{Analisis Data Penelitian}

Penelitian ini dilakukan melalui dua tahapan/ prosedur utama yaitu analisis perubahan penggunaan lahan dn model prediksi aliran dengan HEC-HMS.

\subsubsection{Analisis Perubahan Penggunaan lahan}

Untuk mengklasifikasikan penggunaan lahan pada wilayah sasaran dalam penelitian ini, digunakan data citra time series yang ditujukan untuk mendapatkan informasi tentang penggunaan lahan aktual dari setiap tahun penelitian, yaitu petapenggunaan lahan Tahun 2003 yang berasal dari peta RBI, serta peta penggunaan lahan Tahun 2010 yang diklasifikasikan dari citra ALOS-AVNIR dengan resolusi 10 meter. Kedua output peta tersebut mempunyai skala 1:25.000.

Analisis menggunakan aplikasi GIS (ArcGIS9.3). Metodologi untuk analisis perubahan penggunaan lahan adalah dengan menggunakan peta pendukung seperti peta penggunaan lahan, topografi, dan vegetasi sebagai peta referensi.

Dalam penelitian ini digunakan peta yang telah diinterpretasi dan dipublikasi oleh BIG (Badan Informasi Geospasial) tahun 2003 dan peta penggunaan lahan tahun 2010 hasil interpretasi Citra ALOS.

\subsubsection{Model Hidrologi untuk Prediksi Hasil Air}

Tahapan dimulai dengan melakukan proses awal menggunakan Aplikasi Tool HECGeoHMS pada ArcGis terdiri dari langkah-langkah sebagai berikut:

1. Membangun disain model dengan menggunakan HECGeoHMS dengan tahapan: 
a. Melakukan pembentukan sub-DAS dan karakteristiknya dengan data DEM

b. Melakukan input data model, berupa data time series, data grid (data raster penggunaan lahan, tanah, persen penutupan lahan, dan lain lain) serta data hidrologi yang dibutuhkan oleh model yang telah didisain sebelumnya.

c. Membuat Export Format File sebagai data HEC-HMS

2. Dengan menggunakan Aplikasi model HECHMS dilakukan simulasi dengan output berupa debit dan hasil air.

3. Kemudian dilakukan kalibrasi model dengan data hasil observasi atau pengukuran.

4. Setelah model dikalibrasi dan tervalidasi, dilakukan proses analisis dengan membandingkan hasil air untuk setiappenggunaan lahan baik tahun 2003 maupun 2010 . rangka pemanfaatan lahan untuk kegiatan pemanfaatan sumberdaya alam maupun perubahan fungsi pemanfaatan. Peningkatan pemanfaatan sumberdaya alam sebagai akibat dari pertambahan penduduk dan perkembangan ekonomi, konflik kepentingan dan kurang keterpaduan antar sektor, antar wilayah hulu-tengah-hilir yang tidak memperhatikan kondisi lahan dapat menyebabkan kerusakan DAS.

Perubahan penggunaan lahan (landuse change) meliputi pergeseran penggunaan lahan menuju penggunaan lahan yang berbeda (conversion) atau intensifikasi pada penggunaan lahan yang sudah ada. Secara umum perubahan lahan akan mengubah: (a) karakteristik aliran sungai, (b) jumlah aliran permukaan, (c) sifat hidrologis daerah yang bersangkutan (Mayer dan Turner, 1994; Feri, 2007).

Perubahan penggunaan lahan subDAS Cisadane hulu diperoleh dengan membandingkan dua peta dan

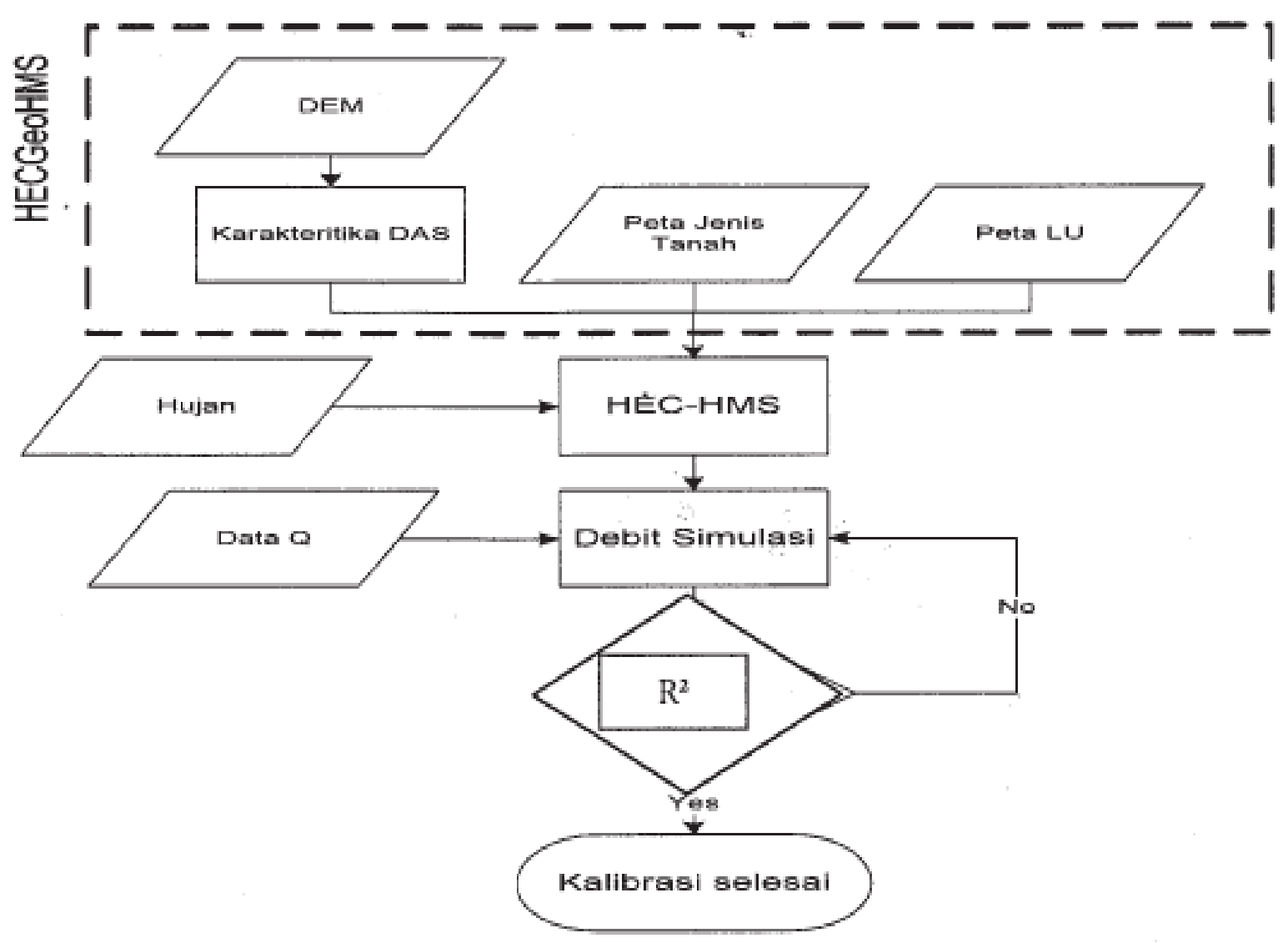

Gambar 1. Tahap Pengembangan Model dengan HECGeoHMS dan HEC-HMS

\section{HASIL DAN PEMBAHASAN}

\subsection{Perubahan Penggunaan Lahan}

Perubahan penggunaan lahan merupakan bentuk peralihan dari penggunaan lahan sebelumnya ke penggunaan lain berikutnya. Pada sebagian besar wilayah DAS perubahan penggunaan lahan cenderung mengurangi penutupan lahan, baik dalam data penggunaan lahan yaitu klasifikasi citra ALOS Tahun 2010 dengan Peta Rupa Bumi Indonesia (RBI) tahun 2003. Hasil perubahan penggunaan lahan (cross tabel) diperlihatkan pada Tabel 1 dan Tabel 2. Dari data tersebut tampak adanya perubahan yang cukup bervariasi. Perubahan terbesar terjadi pada tutupan hutan yang penambahannya mencapai 223,78 ha atau bertambah $1,01 \%$ dalam total luas 
subDAS, menjadi $22,82 \%$. Penambahan luas hutan yang tampak dalam peta citra Alos tahun 2010, diakibatkan oleh perubahan penutupan lahan di sebagian tegalan, semak belukar dan kebun. Hal ini dapat disebabkan oleh beberapa kemungkinan, antara lain berhasilnya upaya rehabilitasi yang meningkatkan luas penutupan lahan pada kriteria hutan dan kemungkinan karena adanya pengalihfungsian kawasan hutan yang dikelola oleh Perum Perhutani sebagai areal PHBM (Pemanfaatan Hutan Bersama Masyarakat) menjadi bagian dari wilayah Taman Nasional Gede Pangrango. Lokasi penambahan terdapat di sekitar arah barat daya Taman Nasional Gede Pangrango.

Perubahan selanjutnya terjadi pada fungsi pemukiman. Pertumbuhan pemukimandi DAS Cisadane Hulu mencapai 0,97\%. Areal pemukiman dalam peta RBI tahun 2003 seluas $3.029,87$ ha.
Sedangkan pada peta tahun 2011 menjadi 3.244.65 ha, meningkat 214,78 ha. Penambahan pemukiman relatif menyebar, namun dapat terlihat di sekitar utara dan selatan DAS. Perubahan tambah terjadi juga pada rumput/tanah kosong seluas 85,63 ha atau setara dengan 0,39\% dari luas DAS Cisadane Hulu hingga menjadi $2,12 \%$. Disamping penambahan, terjadi juga pengurangan luas pada semak belukar seluas 225,64 ha setara dengan $1,01 \%$, pada tegalan/ ladang seluas 145,23 ha yang setara dengan $0,66 \%$, sawah irigasi seluas 124,92 ha, tegalan/ladang seluas 143,23 ha, sawah tadah hujan 30,67 ha, kebun/ perkebunan seluas 9,92 ha seerta badan air sebesar 0,37 ha.

Dampak perubahan lahan di DAS Cisadane hulu ini selanjutnya akan di simulasi dengan Model Hidrologi HEC-HMS untuk melihat pengaruhnya terhadap kondisi hidrologi debit (penggunaan air).

Tabel 1. Luasan perubahan penggunaan lahan di DAS Cisadane Hulu

\begin{tabular}{|c|c|c|c|c|c|c|}
\hline \multirow{2}{*}{ No. } & \multirow{2}{*}{ Penggunaan Lahan } & \multicolumn{2}{|c|}{2003} & \multicolumn{2}{|c|}{2010} & \multirow{2}{*}{ Perubahan } \\
\hline & & $\mathrm{Ha}$ & $\%$ & $\mathrm{Ha}$ & $\%$ & \\
\hline 1 & Air Tawar & 73.51 & 0.33 & 73.14 & 0.33 & -0.37 \\
\hline 2 & Belukar/Semak & $2,085.83$ & 9.38 & $1,860.19$ & 8.37 & -225.64 \\
\hline 3 & Tanah Berbatu & 1.75 & 0.01 & 1.75 & 0.01 & 0.00 \\
\hline 4 & Gedung & 10.08 & 0.05 & 22.54 & 0.10 & 12.46 \\
\hline 5 & Hutan & $4,848.07$ & 21.81 & $5,071.85$ & 22.82 & 223.78 \\
\hline 6 & Kebun/Perkebunan & $3,571.19$ & 16.07 & $3,561.27$ & 16.02 & -9.92 \\
\hline 7 & Pemukiman & $3,029.87$ & 13.63 & $3,244.65$ & 14.60 & 214.78 \\
\hline 8 & Rumput/Tanah Kosong & 385.43 & 1.73 & 471.16 & 2.12 & 85.63 \\
\hline 9 & Sawah Irigasi & $1,382.50$ & 6.22 & $1,257.58$ & 5.66 & -124.92 \\
\hline 10 & Sawah Tadah Hujan & $3,068.51$ & 13.80 & $3,037.84$ & 13.67 & -30.67 \\
\hline \multirow[t]{2}{*}{11} & Tegalan/Ladang & $3,771.25$ & 16.97 & $3,626.02$ & 16.31 & -145.23 \\
\hline & TOTAL & $22,228.01$ & 100.00 & $22,228.01$ & 100.00 & \\
\hline
\end{tabular}

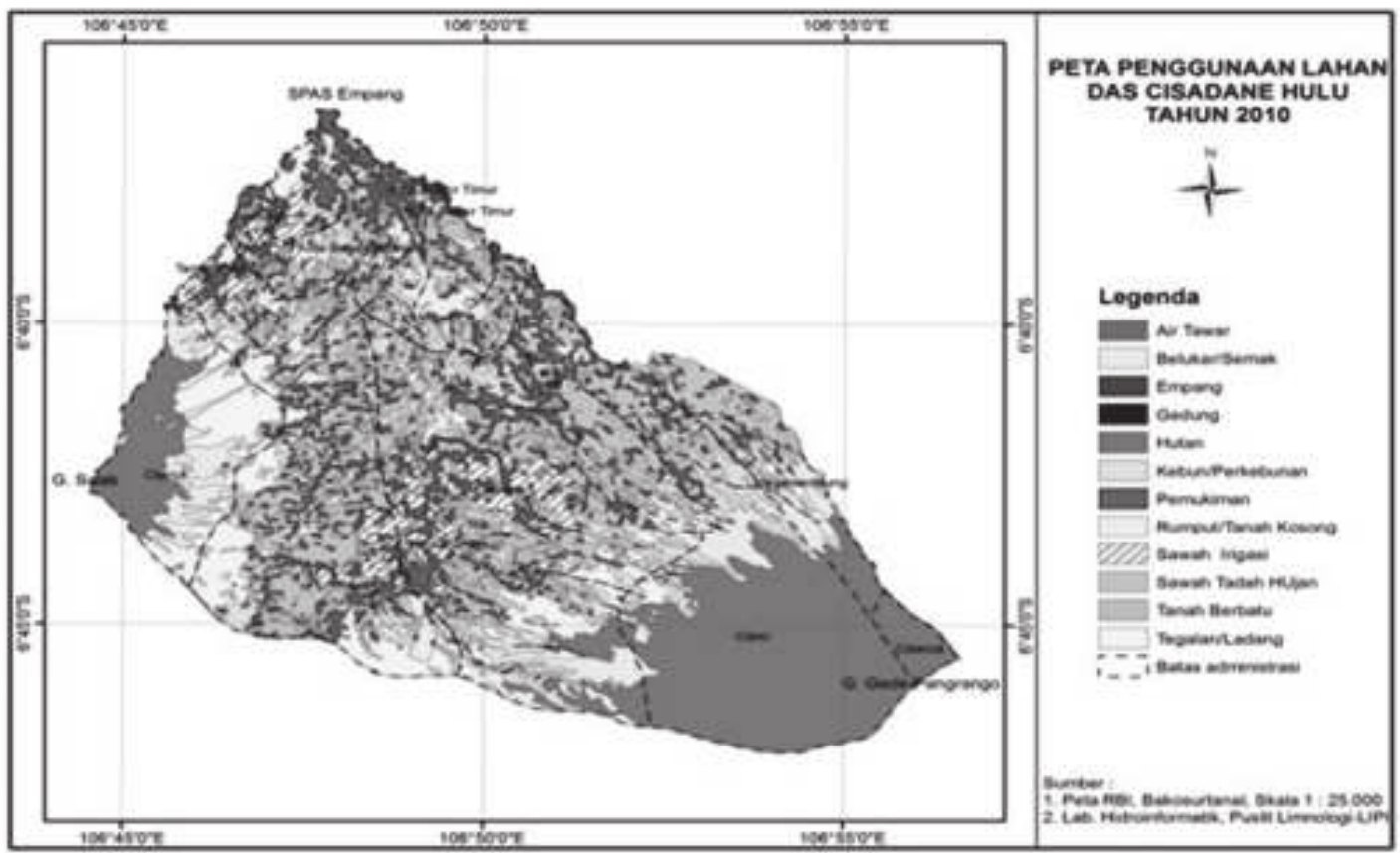

Gambar 2. Peta Penggunaan Lahan DAS Cisadane Hulu Tahun 2010 


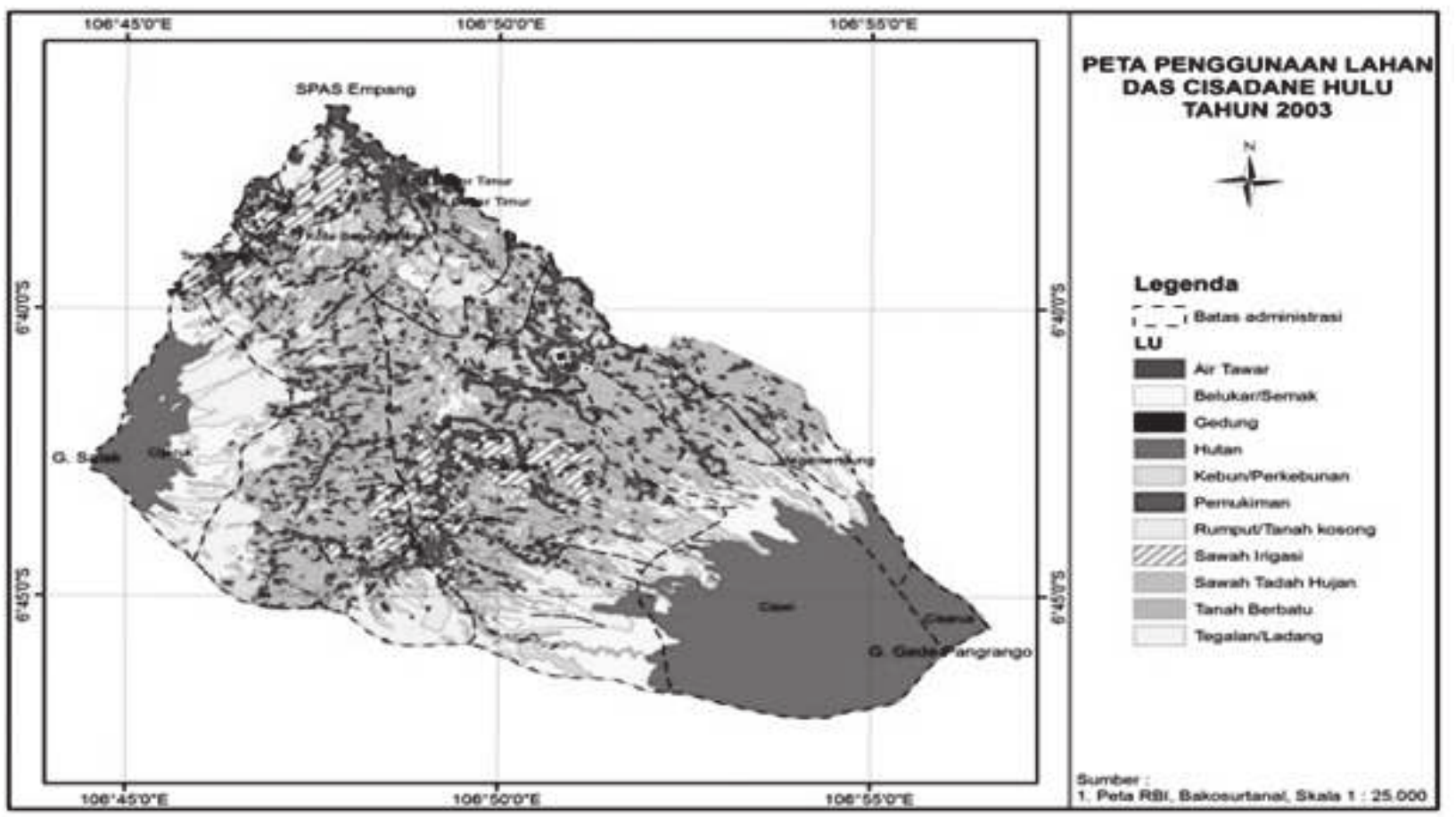

Gambar 3. Penggunaan Lahan DAS Cisadane Hulu Tahun 2003

\subsection{Model Hidrologi HEC-HMS}

\subsubsection{Parameter Masukan Model HEC-HMS}

\section{Penentuan Nilai Bilangan Kurva (Curve} Number) Dan Nilai Persen Impervious

Menurut Asdak (2007) nilai bilangan kurva aliran permukaan/ Curve Number (CN) menunjukkan potensi air larian atau aliran permukaan untuk curah hujan tertentu. Nilai CN bervarisasi dari 0 (nol) sampai 100 (seratus). Nilai bilangan kurva ini ditentukan berdasarkan sifat-sifat tanah, keadaan hidrologi, perlakuan budidaya tanaman. penggunaan lahan dan kandungan air tanah lima hari sebelumnya. Berdasarkan peta tanah semidetail di wilayah DAS Cisadane, maka pada DAS Cisadane Hulu terdapat empat kelompok hidrologi tanah. yaitu kelompok A, B, C dan D (Tabel 3).

Tabel 2. Luasan Kelompok hidrologi tanah di DAS Cisadane Hulu

\begin{tabular}{crr}
\hline Kelompok Hidrologi Tanah & Luas(Ha) & Persentase(\%) \\
\hline A & 2,11584 & 0,01 \\
B & 7173,82922 & 29,38 \\
C & 15483,7823 & 63,41 \\
D & 1697,7099 & 6,95 \\
Perairan & 61,04735 & 0,25 \\
Total & 24418,48461 & 100 \\
\hline
\end{tabular}

Peta kurva aliran diperoleh dari tumpang susun peta penggunaan lahan dengan peta kelompok hidrologi tanah. Selain bilangan kurva, parameter yang juga berpengaruh terhadap volume limpasan suatu DAS adalah luas daerah impervious atau kekedapan terhadap air. Impervious area dari suatu DAS adalah luasan dari DAS dimana semua kontribusi dari presipitasi akan menjadi limpasan langsung tanpa mengalami infiltrasi, evaporasi ataupun bentuk kehilangan air lainnya (USACE, 2001). Penentuan nilai impervious area berdasarkan tipe penggunaan lahan dan faktor imperviousness (kekedapan)

\section{Setup Model dengan Hec-GeoHMS dan Pemodelan Hidrologi HEC-HMS}

Geoprocessing yang dilakukan oleh HECGeoHMS adalah untuk mengubah data DEM, CN dan impervious menjadi parameter dan membangun sub DAS kedalam format yang sesuai untuk model hidrologi HEC-HMS. Aplikasi dilakukan melalui beberapa langkah pengolahan data yang tergantung pada pengaturan model. Hasil pengolahan dengan HEc-GeoHMS dengan threshold 1000 cell atau dengan luasan $8 \mathrm{~km}^{2}$ terbentuk 19 sub DAS seperti yang diperlihatkan pada Gambar 3. Setiap sub DAS yang terbentuk akan menjadi dasar dalam pemasukan parameter input seperti Bilangan Kurva dan nilai persen impervious.

Aplikasi HEC-GeoHMS yang merupakan tools dalam ArcGIS berfungsi untuk menyiapkan data karakteristik DAS sesuai dengan format yang dibutuhkan oleh Model Hidrologi HEC-HMS. Aplikasi ini mengatur subDAS-SubDAS yang dibentuk kemudian membangun skematik model seperti yang diperlihatkan padaGambar 4.Pemodelan ini membagi DAS dalam sub-subDAS kecil atau basin. Penyusunan basin model merupakan salah satu 


\begin{tabular}{|c|c|c|c|c|c|c|c|c|c|c|c|c|c|}
\hline & 몷 푱 & $\begin{array}{l}\bar{n} \\
\bar{n}\end{array}$ & 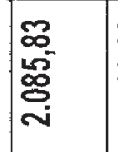 & : & 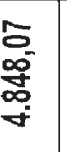 & 旁 & 荡 & 管 & 占 & 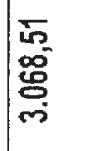 & $\stackrel{2}{\underline{F}}$ & 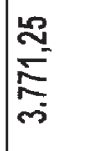 & 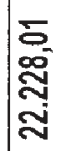 \\
\hline & 蛋 & & 8 & & & 8 & 8 & & 8 & & & 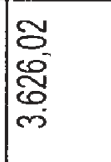 & 路 \\
\hline & 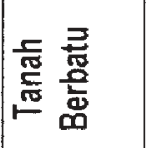 & & & & & & & & & & 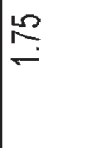 & & $\stackrel{2}{\stackrel{2}{2}}$ \\
\hline & 焉焉 & & & & & 8 & 응 & & & $\begin{array}{l} \\
0 \\
0 \\
0 \\
0 \\
\text { m. }\end{array}$ & & & 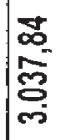 \\
\hline & 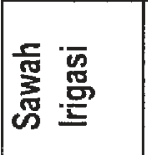 & & & & & & & & 变 & & & 8 & 品 \\
\hline 0 & 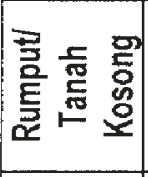 & & $\begin{array}{l}\infty \\
m \\
\infty \\
m\end{array}$ & & & $\underset{N}{N}$ & & 䍃 & $\frac{8}{\frac{8}{\sigma}}$ & 电 & & $\mid \begin{array}{c}\infty \\
\infty\end{array}$ & $\frac{\infty}{\frac{\pi}{8}}$ \\
\hline 로 & 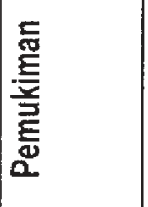 & & $\approx$ & & & 管 & 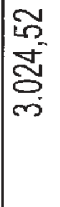 & $\begin{array}{l}\stackrel{\sim}{\sim} \\
\stackrel{\sim}{\sim}\end{array}$ & 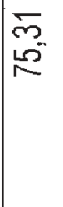 & 票 & & $\begin{array}{c}\bar{N} \\
\text { s. } \\
\text { s. }\end{array}$ & 㞧 \\
\hline & 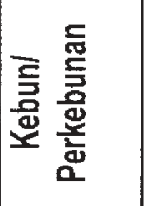 & $\sqrt{5}$ & $\begin{array}{l}\infty \\
\mathbb{R} \\
\text { in }\end{array}$ & & & $\begin{array}{l}\bar{E} \\
\dot{0} \\
\overline{6} \\
\dot{m}\end{array}$ & & 怘 & $\underset{\substack{\infty \\
\sim}}{\sim}$ & $\underset{\delta}{\approx}$ & & 梁 & 空 \\
\hline & $\begin{array}{l}\text { 퐆 } \\
\text { 포 }\end{array}$ & & 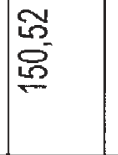 & & 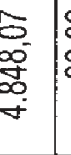 & స్ & & & & & & $\begin{array}{l}8 \\
0 \\
0 \\
6\end{array}$ & 岕 \\
\hline & $\begin{array}{l}\text { 임 } \\
\text { 吉 } \\
\text { J }\end{array}$ & & & 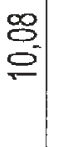 & & $\mathscr{O}$ & 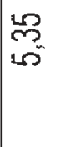 & & 8 & 艿 & & $\mathscr{B}$ & 芯 \\
\hline & 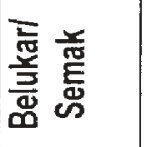 & & $\mid$ & & & & & $\bar{\delta}$ & & & & $\underset{m}{\bar{m}}$ & 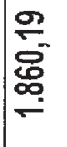 \\
\hline & 言怘 & $\frac{\sigma}{m^{2}}$ & & & & & & & & & & 8 & $\frac{\pi}{2}$ \\
\hline & & 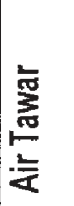 & 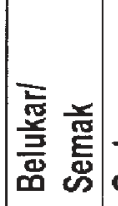 & 宫 & 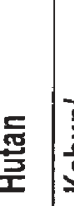 & 总 & 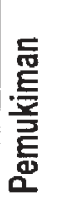 & 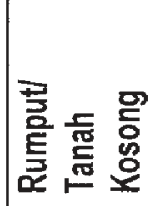 & 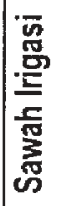 & 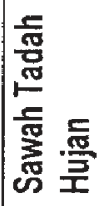 & 点 & 胥 & 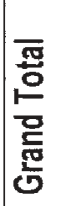 \\
\hline
\end{tabular}


tahap penting dalam analisa system hidrologi menggunakanHEC-HMS. Dalam basin modelperlu disusun konfigurasi yang menggambarkan representasi fisik dari suatu subDAS berdasarkan elemen-elemen hidrologi.

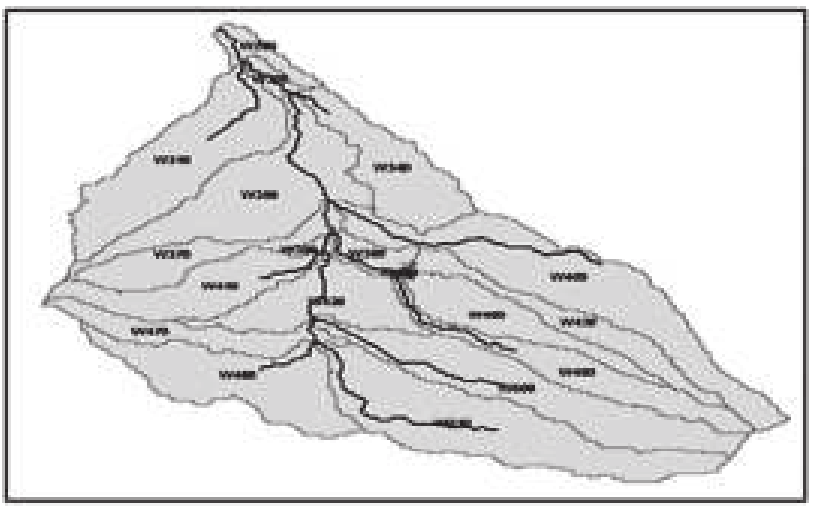

Gambar 4. Pembatasan subDAS dengan HEC-GeoHMS

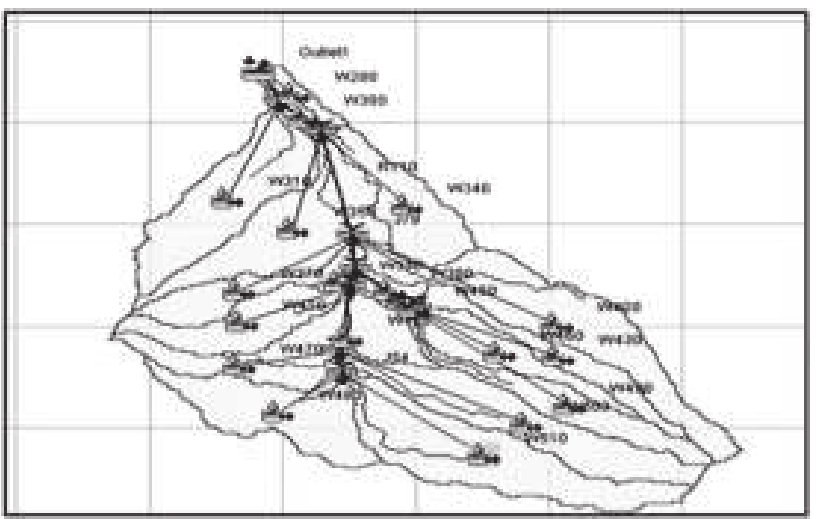

Gambar 5. Skematik model HEC-HMS

Terdapat tujuh elemen hidrologi yang tersedia dalam HEC-HMS. yaitu Subbasin. Reach. Reservoir. Junction. Diversion. Source. dan Sink. Pada penelitian ini elemen hidrologi yang digunakan untuk mengkonfigurasi SubDAS Cisadane Hulu terdiri dari 19 subbasin. 9 reach. 9 junction dan 1 sink.

\subsubsection{Hasil Simulasi MODEL HEC-HMS}

Simulasi dilakukan pada rentang waktu tahun 2009 sampai dengan 2010 dengan menggunakan data hujan harian dari tiga stasiun yaitu; Empang, Pasirjaya dan Citeko. Ketiga stasiun hujan ini digunakan dengan pertimbangan lokasinya berada atau dekat dengan DAS dan ketersedian data. Rentang waktu ini sesuai dengan ketersediaan data debit dan penggunaan lahan di DAS Cisadane Hulu. Hasil simulasi diperlihatkan pada Gambar 5. Hasil simulasi masih memperlihatkan perbedaan dibandingkan dengan hasil pengukuran debit di stasiun Empang. Hasil korelasi diperlihatkan pada Gambar 6 dimana statistic error adalah 0,18 masih belum cukup untuk digunakan sehingga harus dilakukan kalibrasi.

\subsubsection{Kalibrasi Model}

Untuk memperoleh nilai debit simulasi yang mendekati nilai pengukuran, dilakukan Kalibrasi dengan menggunakan model HEC-HMS.Kalibrasi disesuaikan pada beberapa parameter sesuai dengan metoda yang digunakan.

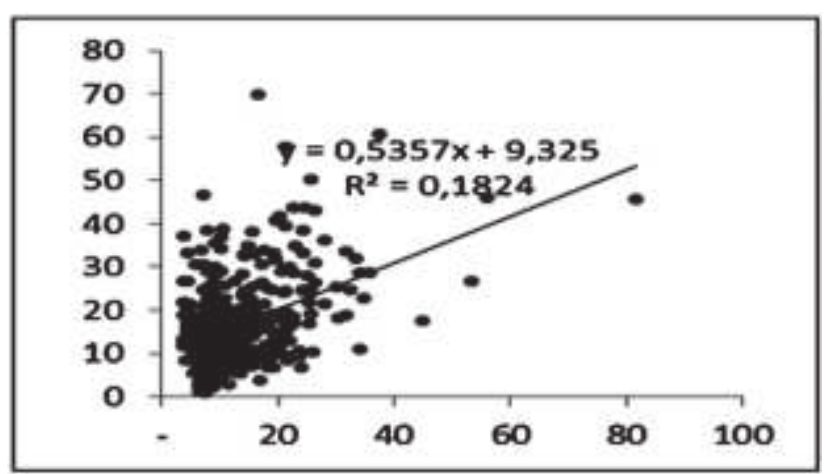

Gambar 7. Perbandingan Statistik antara debit simulasi dan debit pengukuran

Parameter yang paling mempengaruhi pada pemodelan ini adalah nilai kurva aliran $(\mathrm{CN})$ dimana pada proses kalibrasi nilai ini menggunakan 50\% dari

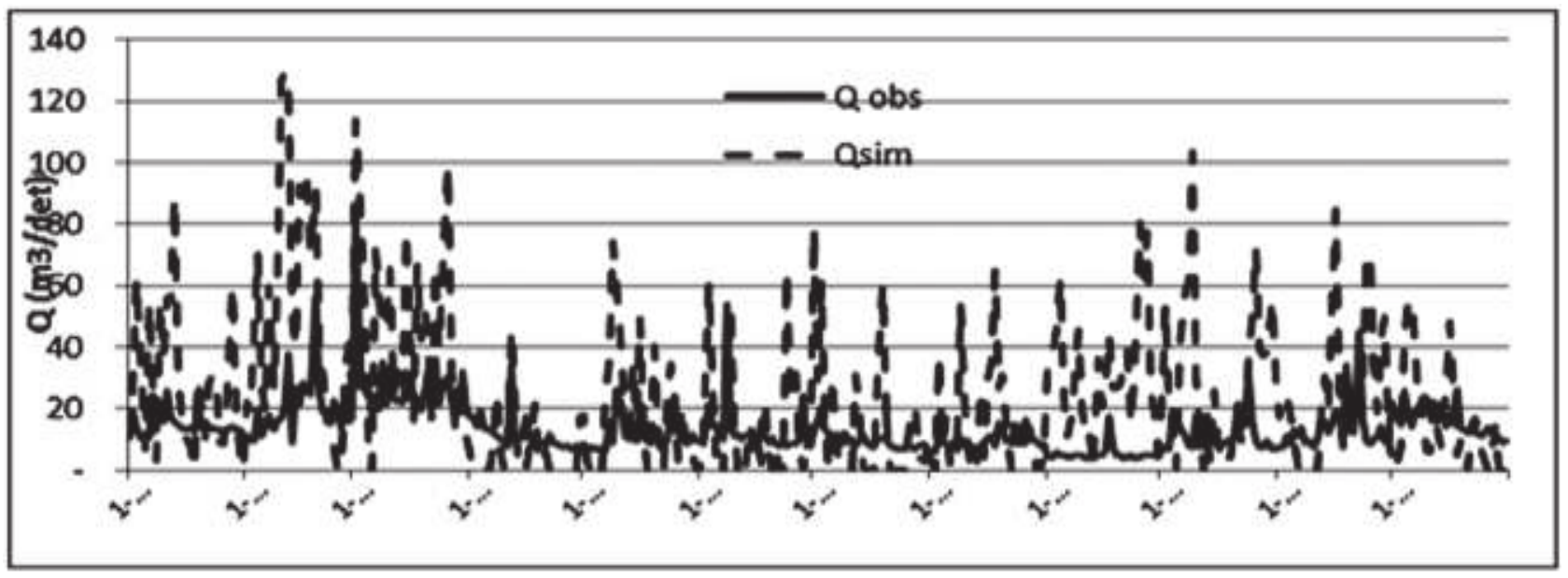

Gambar 6. Perbandingan antara debit simulasi dan hasil pengukuran DAS Cisadane Hulu Tahun 2010 
data sebelumnya. Hal ini berdasarkan hasil analisis dari perbandingan debit simulasi dan pengukuran yang memperlihatkan debit puncak dari simulasi lebih besar dari nilai debit pengukuran. Sedangkan nilai baseflow simulasi lebih rendah dari baseflow pengukuran.Selanjutnya parameter lain yang dikalibrasi yaitu pada parameter baseflow dan nilai lag time pada parameter reach.

Metoda baseflow yang digunakan pada pemodelan ini adalah recession method yang mempunyai beberapa elemen yaitu initial discharge. recession constant dan ratio to peak. sedangkan parameter transform menggunakan metoda lagtime Nilai-nilai parameter baseflow dan transform yan digunakan pada proses kalibrasi diperihatkan pad Tabel 4.

Tabel 4.Nilai Beberapa Elemen pada Parameter Baseflow dan Transfor

\begin{tabular}{lcccc}
\hline & \multicolumn{2}{c}{ Base flow } & \multicolumn{2}{c}{ Transform } \\
\cline { 2 - 5 } Subbasin & $\begin{array}{c}\text { Initial Discharge } \\
\text { (m3/det) }\end{array}$ & $\begin{array}{c}\text { Recesion } \\
\text { Constant }\end{array}$ & Ratio to Peak & $\begin{array}{c}\text { Lag Tim } \\
\text { (mnt) }\end{array}$ \\
\hline W510 & 0,03 & 0,9 & 0,4 & 295,59 \\
W480 & 0,03 & 0,8 & 0,4 & 184,15 \\
W500 & 0,03 & 0,9 & 0,4 & 289,03 \\
W470 & 0,03 & 0,8 & 0,5 & 208,26 \\
W420 & 0,025 & 0,9 & 0,4 & 194,95 \\
W410 & 0,03 & 0,9 & 0,5 & 261,24 \\
W460 & 0,03 & 0,7 & 0,5 & 209,08 \\
W430 & 0,025 & 0,8 & 0,5 & 30,36 \\
W490 & 0,03 & 0,8 & 0,4 & 282,32 \\
W450 & 0,025 & 0,9 & 0,5 & 8,27 \\
W380 & 0,03 & 0,8 & 0,5 & 131,58 \\
W390 & 8,5 & 0,9 & 0,4 & 79,07 \\
W400 & 0,03 & 0,1 & 0,25 & 422,23 \\
W370 & 0,03 & 0,75 & 0,4 & 291,05 \\
W350 & 0,03 & 0,1 & 0,4 & 383,18 \\
W340 & 0,03 & 0,8 & 0,4 & 268,01 \\
W310 & 8,5 & 0,1 & 0,4 & 499,68 \\
W300 & 0,03 & 0,8 & 0,4 & 159,72 \\
W280 & 0,03 & 0,9 & 0,3 & 290,18 \\
& & & &
\end{tabular}

Simulasi hasil kalibrasi model diperlihatkan pada Gambar 16. yang dibandingkan dengan hasil pengukuran debit. Hasil kalibrasi dengan menggunakan nilai coefisien error $\left(\mathrm{R}^{2}\right)$ menghasilkan nilai sebesar 0,527 (Gambar 17.). Berdasarkan hasil kalibrasi antara prediksi model dengan hasil pengukuran pada series hujan dan debit pengukuran yang digunakan dapat disimpulkan bahwa model HEC-HMS cukup akurat dan dapat digunakan untuk memprediksi volume aliran permukaan pada proses simulasi perubahan penggunaan lahan terhadap respon hidrologi di DAS Cisadane Hulu.

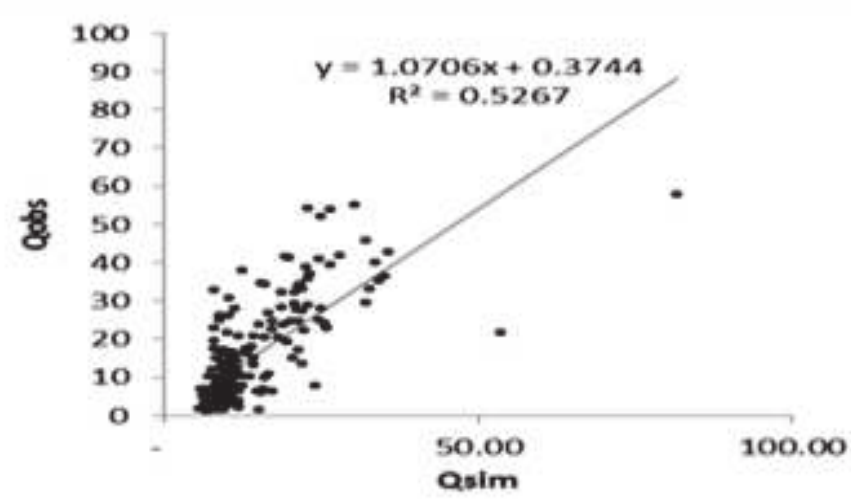

Gambar 9. Perbandingan Statistik Antara Debit Simulasi Hasil Kalibrasi dan Debit Pengukuran

\subsection{Pengaruh Perubahan Penggunaan Lahan dan Skenario Rehabilitasi DAS}

Dampak perubahan penggunaan lahan terhadap respon hidrologi dalam hal ini volume aliran permukaan dengan menggunakan model HEC-HMS dilakukan dengan menggunakan nilai-nilai masukan berdasarkan penggunaan lahan tahun 2003dan 2010. Asumsi yang digunakan adalah bahwa semua parameter masukan model dianggap tetap kecuali parameter bilangan kurva dan persen impervious.

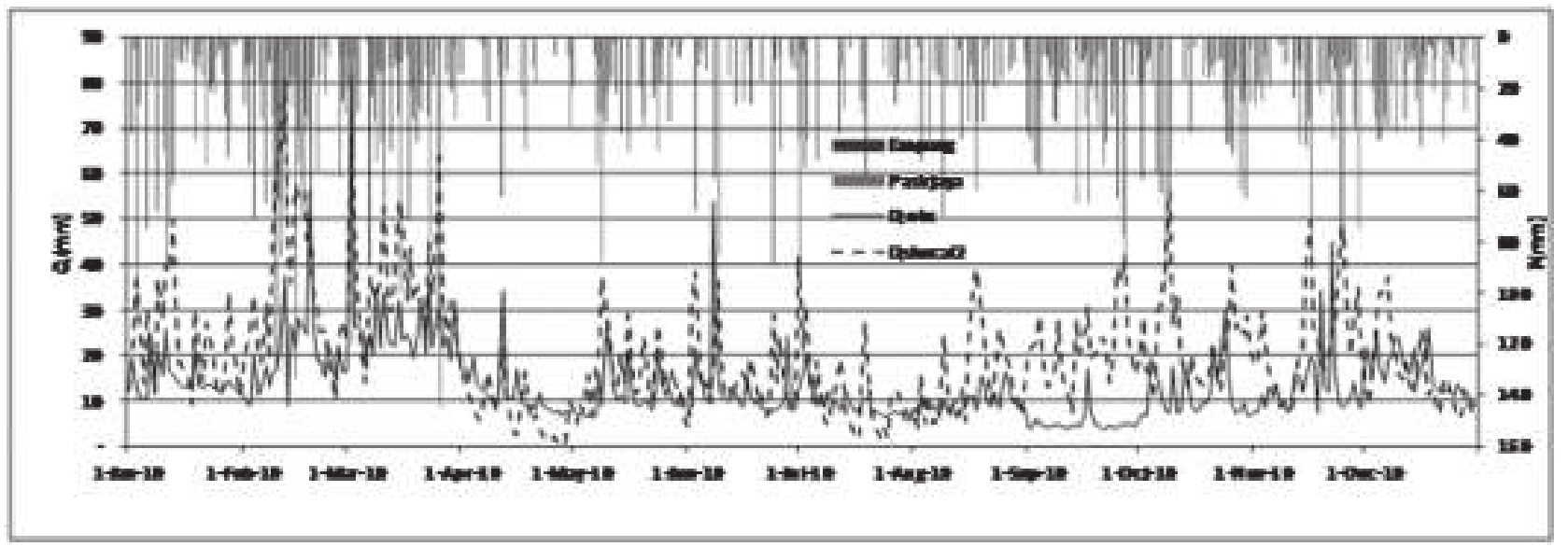

Gambar 8. Perbandingan debit simulasi hasil kalibrasi dan hasil pengukuran DAS Cisadane Hulu Tahun 2010 
Tabel 5. Faktor Imperviousness berdasarkan tipe penggunaan lahan

\begin{tabular}{lc}
\hline Penggunaan Lahan & Faktor Imperviousness (\%) \\
\hline Hutan & 0 \\
Tanah terbuka & 5 \\
Agrikultur & 5 \\
Pemukiman & 30 \\
Komersial & 80 \\
\hline
\end{tabular}

Sumber: USACE. 2000

Simulasi dilakukan pada beberapa kondisi diantaranya pada penggunaan lahan tahun 2010sebagai baseline simulasi yang juga di kalibrasi dan validasi.

Simulasi dilakukan juga pada kondisi penggunaan lahan tahun 2003 untuk membandingkan dengan kondisi yang lebih baik. Untuk rencana perbaikan DAS Cisadane Hulu dibangun dua skenario penggunaan lahan; skenario pertama dilakukan dengan merehabilitasikembali lahan-lahan terbuka pada kawasan hutan lindung menjadi hutan kembali, sedangkan skenario dua dilakukan dengan mengembangkan hutan rakyat pada lahan-lahan kosong dan semak belukar.

Konversi lahan di daerah hulu menyebabkan sebagian besar air hujan yang jatuh di wilayah DAS tersebut tidak dapat diretensikan dengan baik sehingga mengalir dengan cepat kebagian hilir DAS. Peningkatanluas permukiman pada tahun 2010 juga mengakibatkan berkurangnya daerah resapan air, sehingga terjadi peningkatan jumlah curah hujan yang tidak terserapyang mengalir menjadi aliran permukaan.
Berdasarkan hasil prediksi model tersebut maka dapat disimpulkan bahwa perubahan penggunaan lahan di suatu wilayah akan berpengaruh terhadap besarnya volume aliran permukaan. Beberapa parameter digunakan untuk membandingkan hasil simulasi berdasarkan kondisi dan skenario yang dibentuk. yaitu: debit puncak dan water yield. Hasil simulasi diperlihatkan pada Gambar 10 danTabel 7.

Secara umum terjadi peningkatan debit puncak antara penggunaan lahan tahun 2003 dengan 2010 dimana pada outlet Empang debit puncak meningkat dari $81,22 \mathrm{~m}^{3} /$ detik menjadi $81.73 \mathrm{~m}^{3} /$ detik. Secara umum hampir semua SubDAS mengalami kenaikan debit puncak, hanya beberapa subDAS yang mempunyai nilai debit puncak yang tetap. Naiknya debit puncak ini disebabkan lebih banyaknya aliran permukaan akibat perkembangan pemukiman di DAS. hal ini terlihat dengan meningkatnya nilai $\mathrm{CN}$ rata-rata DAS Cisadane Hulu, dari 38,5 menjadi 39,4.

Hasil air (water yield) adalah total limpasan dari suatu daerah pengaliran air (drainage basin) yang disalurkan melalui saluran air permukaan dan akuifer (reservoir air tanah). Pada pemodelan dengan HEC-HMS ini hasil air merupakan salah satu luaran model. Pada simulasi dengan penggunaan lahan tahun 2010 didapatkan hasil air sebesar $2.310,7 \mathrm{~mm}$ per tahun nilai ini lebih kecil dari pada simulasi dengan penggunaan lahan tahun 2003 yang menghasilkan nilai $2.320,1 \mathrm{~mm}$ pertahun. Salah satu penyebab berkurangnya hasil air dapat disebabkan oleh penguapan yang makin tinggi akibat luasan hutan yang bertambah, tetapi penurunan ini tidak terlalu berdampak selama distribusi temporal debit aliran merata sepanjang tahun.

Tabel 6. Nilai bilangan kurva pada beberapa kondisi DAS Cisadane Hulu

\begin{tabular}{|c|c|c|c|c|c|c|c|c|c|}
\hline \multirow{2}{*}{ SubDAS } & & \multicolumn{4}{|c|}{ Basin SlopePersen impervious } & \multicolumn{4}{|c|}{ Curve Number } \\
\hline & & LU 2003 & LU 2010 & Skenario 1 & Skenario 2 & LU 2003 & LU 2010 & Skenario 1 & Skenario 2 \\
\hline W280 & 2.0 & 58.1 & 30.1 & 58.1 & 58.1 & 38.6 & 45.5 & 43.04 & 40.43 \\
\hline W300 & 4.0 & 47.4 & 26.4 & 46.6 & 46.0 & 38.2 & 43.0 & 40.53 & 37.80 \\
\hline W310 & 5.0 & 12.6 & 9.5 & 15.2 & 14.5 & 36.5 & 38.1 & 35.20 & 31.97 \\
\hline W340 & 8.0 & 23.5 & 14.8 & 25.8 & 25.2 & 42.9 & 43.1 & 40.79 & 37.37 \\
\hline W350 & 9.0 & 12.4 & 10.2 & 15.1 & 14.3 & 37.9 & 38.8 & 36.27 & 32.67 \\
\hline W370 & 11.0 & 9.1 & 6.7 & 9.2 & 8.8 & 38.7 & 38.6 & 36.16 & 32.11 \\
\hline W380 & 12.0 & 18.8 & 11.3 & 18.1 & 17.9 & 40.8 & 40.8 & 38.10 & 34.98 \\
\hline W390 & 13.0 & 7.8 & 7.9 & 9.2 & 9.4 & 37.2 & 37.6 & 34.81 & 31.26 \\
\hline W400 & 14.0 & 10.4 & 7.4 & 11.0 & 10.9 & 39.5 & 39.7 & 36.80 & 34.05 \\
\hline W410 & 15.0 & 10.0 & 7.7 & 10.6 & 10.5 & 36.6 & 37.7 & 34.92 & 31.44 \\
\hline W420 & 16.0 & 20.8 & 12.7 & 21.1 & 21.1 & 38.5 & 39.8 & 37.34 & 34.43 \\
\hline W430 & 17.0 & 5.7 & 4.0 & 6.0 & 5.8 & 37.3 & 37.5 & 34.53 & 32.18 \\
\hline W450 & 19.0 & 2.3 & 5.0 & 8.4 & 6.2 & 40.0 & 39.7 & 37.54 & 34.74 \\
\hline W460 & 20.0 & 8.9 & 6.6 & 9.5 & 9.3 & 39.6 & 39.7 & 36.88 & 33.87 \\
\hline W470 & 21.0 & 9.2 & 7.1 & 9.8 & 9.6 & 37.0 & 37.8 & 35.04 & 31.44 \\
\hline W480 & 22.0 & 12.4 & 10.5 & 14.8 & 14.1 & 39.4 & 40.0 & 37.58 & 32.89 \\
\hline W490 & 23.0 & 4.5 & 2.7 & 4.3 & 4.3 & 36.9 & 36.9 & 34.25 & 31.39 \\
\hline W500 & 24.0 & 5.5 & 3.8 & 5.6 & 5.6 & 37.4 & 37.5 & 34.95 & 31.68 \\
\hline W510 & 25.0 & 3.8 & 3.1 & 4.0 & 4.2 & 37.6 & 37.6 & 34.51 & 31.60 \\
\hline Rata-rata & 14.7 & 14.9 & 9.9 & 15.9 & 15.6 & 38.5 & 39.4 & 36.8 & 33.6 \\
\hline
\end{tabular}




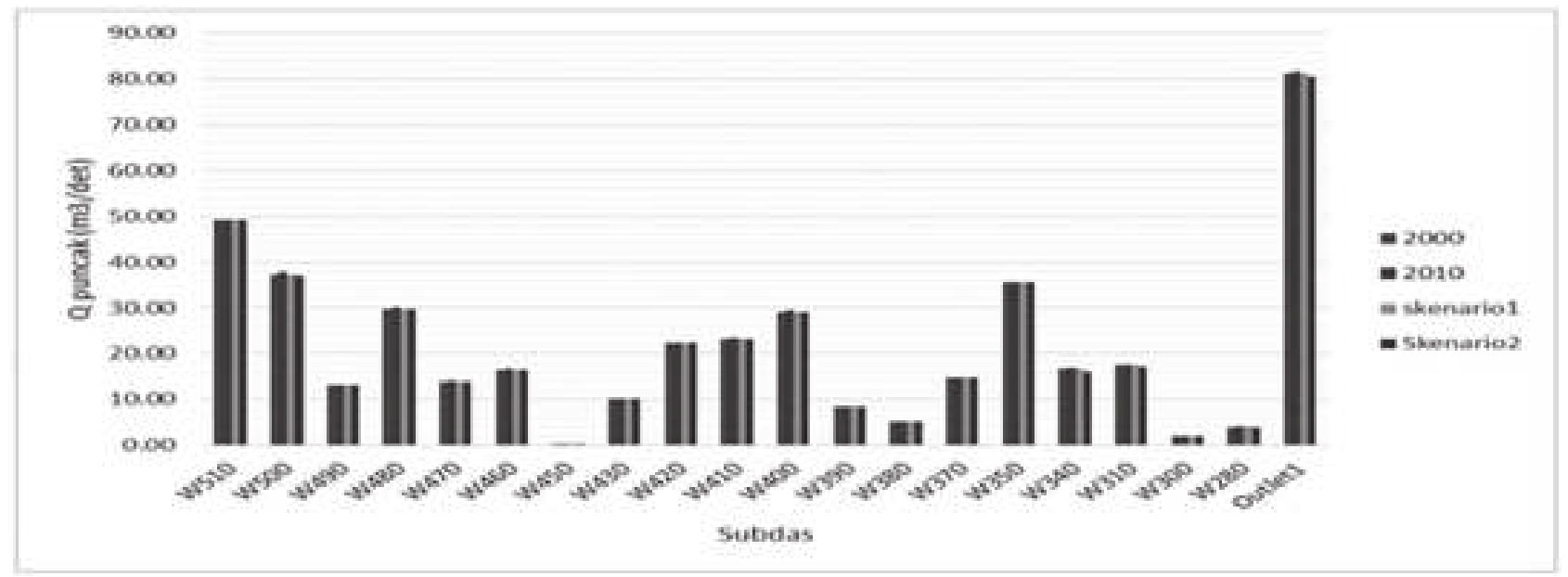

Gambar 10. Debit puncak hasil simulasi model pada beberapa kondisi dan skenario

Skenario-skenario yang dibentuk dimaksudkan untuk perbaikan dan rehabilitasi lahan di DAS Empang (DAS Cisadane Hulu) dari dua skenario yang dibangun diperoleh hasil simulasi seperti yang diperlihatkan pada Gambar 19 dan tabel 10 yang memperlihatkan nilai debit puncak yang lebih baik.Pada skenario 2 nilai debit puncak $(\mathrm{Qp})$ mencapai $80.67 \mathrm{~m}^{3} /$ detik dibandingkan pada skenario 1 dengan nilai Qp; $81.23 \mathrm{~m}^{3} /$ detik nilai Qp ini malah lebih rendah dibandingkan dengan simulasi pada penggunaan lahan tahun 2003.

Tabel 7. Hasil Air dari simulasi model untuk debit puncak pada beberapa kondisi di DAS Cisadane Hulu

\begin{tabular}{lrrrrr}
\hline Subdas & Luas $\left(\mathrm{km}^{2}\right)$ & LU 2003 & LU 2010 & Scenario 1 & Skenario 2 \\
\hline W510 & 27.97 & 49.13 & 49.29 & 49.13 & 49.13 \\
W500 & 21.47 & 37.10 & 37.85 & 37.10 & 36.98 \\
W490 & 11.83 & 13.11 & 13.11 & 13.11 & 13.11 \\
W480 & 18.27 & 29.74 & 30.24 & 29.74 & 29.72 \\
W470 & 8.22 & 13.88 & 14.16 & 13.88 & 13.85 \\
W460 & 10.21 & 16.55 & 16.72 & 16.55 & 16.55 \\
W450 & 0.03 & 0.03 & 0.04 & 0.04 & 0.03 \\
W430 & 9.09 & 10.22 & 10.22 & 10.22 & 10.22 \\
W420 & 12.71 & 22.34 & 22.40 & 22.34 & 22.34 \\
W410 & 12.51 & 23.22 & 23.43 & 23.22 & 23.21 \\
W400 & 28.39 & 29.16 & 29.62 & 29.16 & 29.16 \\
W390 & 0.85 & 8.50 & 8.50 & 8.50 & 8.50 \\
W380 & 3.01 & 5.16 & 5.18 & 5.16 & 5.16 \\
W370 & 9.06 & 14.71 & 14.74 & 14.71 & 14.71 \\
W350 & 23.18 & 35.58 & 35.58 & 35.58 & 35.58 \\
W340 & 13.16 & 16.63 & 16.85 & 16.60 & 15.98 \\
W310 & 22.46 & 17.55 & 26.78 & 17.55 & 17.22 \\
W300 & 1.63 & 2.05 & 2.09 & 2.08 & 2.02 \\
W280 & 3.03 & 3.89 & 4.00 & 3.94 & 3.90 \\
Outlet1 & 237.09 & 81.22 & 81.73 & 81.23 & 80.67 \\
\hline
\end{tabular}

Perubahan penggunaan lahan hampir pasti mengikuti pola dari jenis penggunaan hutan ke pertanian,. perkebunan. dan berlanjut ke permukiman sejalan dengan perkembangan wilayah perkotaan. Perubahan demikian jelas sangat berpengaruh terhadap neraca air wilayah dan rezim hidrologi DAS bersangkutan (Pawitan. 2004). DAS Cisadane Hulu berdasarkan penggunaan lahan tahun 2003 dengan 2010 telah mengalami perubahan yang merubah kondisi hidrologi, walaupun tutupan hutan bertambah tetapi dampak dari perkembangan pemukiman (urban growth) mengakibatkan naiknya debit puncak. Skenario yang dikembangkan pada pemodelan ini dapat digunakan sebagai arahan dalam perencanaan pengelolaan DAS kedepan. Dari hasil simulasi pada ke dua skenario menunjukan skenario kedua menghasilkan kondisi hidrologi lebih baik.

\section{SIMPULAN DAN SARAN}

\subsection{Kesimpulan}

1. Selama kurun waktu 2003 - 2010 terjadi perubahan penggunaan lahan di DAS Cisadane Hulu. Luas Hutan bertambah 223,78 ha, pemukiman 214,78 ha, rumput/tanah kosong 85 , 73 ha, dan gedung 12, 64 ha. Terjadi pengurangan luas semak belukar 225,64 ha, tegalan/ladang 145,92 ha, sawah irigasi 124, 92 ha, sawah tadah hujan 30,67 ha, dan kebun/ perkebunan seluas 9,92 ha.

2. Secara umum terjadi peningkatan debit puncak antara penggunaan lahan tahun 2003 dengan tahun 2010 dari nilai $81,22 \mathrm{~m}^{3} /$ detik menjadi $81,73 \mathrm{~m}^{3} /$ detik. Secara umum hampir semua subDAS mengalami kenaikan debit puncak. Naiknya debit puncak ini dapat disebabkan oleh meningkatnya aliran permukaan akibat perkembangan pemukiman yang terlihat dari meningkatnya nilai $\mathrm{CN}$ rata-rata DAS Cisadane Hulu dari 38,5 menjadi 39,4.

3. Hasil simulasi dengan penggunaan lahan tahun 2010 didapatkan hasil air (water yield) sebesar $2.310,7 \mathrm{~mm} /$ tahun. Sedangkan hasil simulasi penggunaan lahan untuk tahun 2003 diperoleh hasil air dengan nilai $2.320,1 \mathrm{~mm} /$ tahun. 
4. Hasil simulasi model memperlihatkan skenario rehabilitasi DAS dengan pengembangan hutan rakyat pada beberapa subDAS dengan semak/ belukar dan rumput/lahan kosong menghasilkan kondisi hidrologi lebih baik dari kondisi tahun 2003 dengan debit puncak sebesar $80,67 \mathrm{~m}^{3 /}$ detik.

\subsection{Saran}

1. Hasil simulasi terhadap subDAS dengan penutupan lahan yang kurang melalui skenario pengembangan hutan rakyat tampak dapat menurunkan volume aliran permukaan. Kondisi tersebut dapat digunakan sebagai arahan dalam perencanaan pengelolaan DAS khususnya di DAS Cisadane Hulu.

2. Mengingat sebagian besar wilayah pada DAS Cisadane Hulu mempunyai kemiringan di atas $15 \%$, maka pemilihan jenis tanaman yang dikembangkan harus memperhatikan kondisi dan jenis tanahnya.

3. Pada perencanaan pengelolaan DAS yang akan datang diharapkan metoda ini dapat digunakan sebagai salah satu pertimbangan untuk mendapat arahan penggunaan lahan melalui kegiatan vegetatif diantaranya berupa pembangunan hutan rakyat.

\section{DAFTAR PUSTAKA}

Adnyana. I.W.S. 2011. "Perubahan Penggunaan Lahan di Kawasan Bedugul" dalam: Adnyana. I.W.S.. Arthana. I.W.. As-Syakur. A.R.. editor. Perubahan Penggunaan Lahan dan Daya Dukung Lingkungan. Udayana University Press. 1-10. Denpasar.

Asdak. C. 2007. Hydrologi and Pengelolaan Daerah Aliran Sungai. Cetakan Ketiga. Gajah Mada University Press. Jogyakarta.

Feri. T. 2007. "Analisis Perubahan Lahan dan Keterkaitannya dengan Fluktuasi Debit Sungai di Sub-Das Antokan Propinsi Sumatera Barat". Thesis. SPS-IPB. Bogor.

Kartiwa. B.. Runtunuwu. E.. Adi. S.H.. Heryani. N. dan Sutrisno. N. 2005. "Sistem Informasi Hidrologi untuk Pengelolaan Sumber Daya Air DAS Citarum dalam Pasandaran”. E.. Pawitan. H. dan Amien. I. eds.: Sistem Informasi Sumberdaya Iklim dan Air. Balai Penelitian Agroklimat dan Hidrologi. Bogor. 121-140.

U.S. Army Corps of Engineers (US ACE). Hydrologic Engineering Center. 2009. HEC-GeoHMS. GeoSpatial Hydrology Model Extension. User's Manual Version 4.2. Davis. California. 